\title{
Regional Expression of NAD(P)H Oxidase and Superoxide Dismutase in the Brain of Rats with Neurogenic Hypertension
}

\author{
Yongli Bai $^{\mathrm{a}}$ Bahman Jabbari $^{\mathrm{b}}$ Shaohua Ye ${ }^{c}$ Vito M. Campese ${ }^{c}$ \\ Nosratola D. Vaziri ${ }^{a}$ \\ a Division of Nephrology and Hypertension, University of California, Irvine, Calif., b Department of Neurology, \\ Yale University, New Haven, Conn., and 'Division of Nephrology, Keck School of Medicine, University of Southern \\ California, Los Angeles, Calif., USA
}

\section{Key Words}

Hypertension · Sympathetic activity $\cdot \mathrm{NAD}(\mathrm{P}) \mathrm{H}$ oxidase $\cdot$

Oxidative stress $\cdot$ Reactive oxygen species $\cdot$ Medulla $\cdot$

Brain stem · Pons

\begin{abstract}
Background: Single injection of small quantities of phenol into the kidney cortex causes hypertension which is mediated by renal afferent sympathetic pathway activation. This phenomenon can be prevented by superoxide dismutase (SOD) infusion in the lateral ventricle, suggesting the role of superoxide $\left(\mathrm{O}_{\overline{2}}^{\overline{ }}\right)$ in noradrenergic control of arterial pressure. Since $\mathrm{NAD}(\mathrm{P}) \mathrm{H}$ oxidase is a major source of $\mathrm{O}_{\overline{2}}$, we tested the hypothesis that hypertension in this model may be associated with upregulation of $\mathrm{NAD}(\mathrm{P}) \mathrm{H}$ oxidase in relevant regions of brain. Methods: NAD(P)H oxidase subunits, mitochondrial (MnSOD) and cytoplasmic (CuZnSOD) SOD were measured in rats 4 weeks after injection of phenol or saline in the left kidney cortex. Results: Phenol-injected rats exhibited hypertension, upregulation of $\mathrm{gp} 91^{\text {phox }}, \mathrm{p} 22^{\text {phox }}, \mathrm{p} 47^{\text {phox }}$ and $\mathrm{p} 67^{\text {phox }}$ in the medulla, gp $91^{\text {phox }}$ and $\mathrm{p} 22^{\text {phox }}$ in pons and gp91 ${ }^{\text {phox }}$ in hypothalamus. This was associated with upregu-
\end{abstract}

lation of MnSOD with little change in CuZnSOD. Conclusions: Chronic hypertension in phenol-injected rats is associated with upregulation of $\mathrm{NAD}(\mathrm{P}) \mathrm{H}$ oxidase and hence increased $\mathrm{O}_{\dot{2}}^{\bar{z}}$ production capacity in the key regions of the brain involved in regulation of blood pressure. Since reactive oxygen species can intensify central noradrenergic activity, the observed maladaptive changes may contribute to the genesis and maintenance of the associated hypertension.

Copyright $\odot 2008$ S. Karger AG, Basel

\section{Introduction}

Kidney is a sensory organ which is richly innervated with mechano- and chemosensitive afferent nerve fibers [1-6] directly projecting to the regions of the central nervous system involved in regulation of arterial pressure [7, 8]. Via modification of proteins and other molecules, exposure to high concentrations of phenol can lead to tissue necrosis and scar formation. Single injection of a small quantity of phenol into the cortex of one kidney results in development of neurogenic hypertension (HTN) in genetically-normal rats $[9,10]$. The associated HTN persists

\section{KARGER}

() 2008 S. Karger AG, Basel

Fax +41613061234 E-Mail karger@karger.ch www.karger.com www.karger.com/ajn
Nosratola D. Vaziri, MD, MACP

University of California, Irvine, Division of Nephrology and Hypertension

101 The City Drive, Bldg 53, Rm 125, Rt 81

Orange, CA 92868 (USA)

Tel. +1 714456 5142, Fax +1 714456 6034, E-Mail ndvaziri@uci.edu 
long after complete healing of the initial injury and recession of the lesion to a microscopic scar. The intrarenal lesion in this model causes activation of the renal afferent sympathetic pathway which integrates with central regulatory brain regions and results in activation of the corresponding renal efferent pathway. The latter, in turn, raises arterial pressure by augmenting renal vascular resistance and tubular sodium reabsorption and modulating pressure natriuresis [11]. The role of activation of renal afferent sympathetic pathway in the pathogenesis of HTN in this model is enforced by the observation that HTN in this model is prevented by renal denervation prior to phenol injection [12]

Brain stem control of blood pressure is primarily served through three medullary nuclei which influence activities of sympathetic and parasympathetic nerves. Rostral ventrolateral medulla (RVLM) is the main source of sympathetic outflow to preganglionic sympathetic fibers, whereas nucleus ambiguous is the center of parasympathetic activity. The functions of these nuclei are influenced by the nucleus of tractus solitarius (NTS) which receives afferent connections from baro- and chemoreceptors and regulates RVLM activity through the baroreflex signals [13]. Higher in the central nervous system, posterior hypothalamus also regulates the sympathetic outflow [14].

Reactive oxygen species (ROS) play an important role in numerous physiologic and pathologic processes by activating redox-sensitive transcription factors and redoxsensitive signal transduction pathways and by directly reacting with various molecules. There is mounting evidence that ROS contributes to the genesis and/or maintenance of nearly all forms of HTN by several mechanisms including activation of central sympathetic activity [1519]. In this context, increased ROS level has been found in key regions of the brain involved in regulation of cardiovascular functions in animal models of HTN. Moreover, increased ROS level can modulate activity of the central nervous system pathways in ways that support development of hypertension [20]. Reduced nicotinamideadenine dinucleotide phosphate oxidase $[\mathrm{NAD}(\mathrm{P}) \mathrm{H}$ oxidase] is a major source of ROS in the immune cells, cellular constituents of renal, cardiovascular, neuronal and other tissues. In fact, increased ROS production and oxidative stress in animal models of HTN is associated with and largely due to upregulation/activation of this enzyme in the kidney and cardiovascular tissues [21].

In a series of acute experiments, Ye et al. [10] showed that rapid rise in arterial pressure seen shortly after intrarenal injection of phenol in rats is associated with heightened renal sympathetic nerve activity, increased norepinephrine release from posterior hypothalamic nuclei, and increased NAD(P)H oxidase mRNA abundance in the posterior hypothalamic and paraventricular nuclei, as well as locus coeruleus. Furthermore, this study found that the associated rise in arterial pressure and sympathetic activity can be abolished by infusion of cellpermeable superoxide dismutase (SOD) in the lateral ventricle prior to intrarenal injection of phenol. These observations suggest that abrupt stimulation of central sympathetic activity and the associated rise in arterial pressure in this model is mediated by increased production of superoxide by $\mathrm{NAD}(\mathrm{P}) \mathrm{H}$ oxidase in the brain nuclei involved in the noradrenergic control of arterial pressure.

The present study was undertaken to determine protein abundance of the superoxide-generating enzyme, $\mathrm{NAD}(\mathrm{P}) \mathrm{H}$ oxidase, and SOD in the key regions of the brain involved in noradrenergic control of arterial pressure in this model.

\section{Methods}

\section{Animals}

Experiments were performed in male Sprague-Dawley (SD) rats (280-320 g b.w.). Baseline arterial pressure was measured by tail plethysmography. Under general anesthesia with intramuscular injections of sodium pentobarbital $(35 \mathrm{mg} / \mathrm{kg})$, the left kidney was exposed via a dorsal incision and $50 \mu \mathrm{l}$ of $10 \%$ phenol or saline were injected into the lower pole cortex. The incision was then closed and the rats returned to the vivarium, where they were provided free access to food and water. After a 4-week observation period, the rats were placed in individual metabolic cages for a 24-hour urine collection. Subgroups of animals were used for direct measurement of arterial pressure. These animals were anesthetized as described above and placed on a thermostatically controlled warming table to maintain body temperature at $37^{\circ} \mathrm{C}$. A polyethylene catheter (PE-10) was placed into a femoral artery and arterial pressure recorded as described in our earlier studies. Under general anesthesia, the remaining animals were euthanized by exsanguinations using cardiac puncture, the brains were then harvested, medulla, hypothalamus and pons were isolated, snap-frozen in liquid nitrogen and stored at $-70^{\circ} \mathrm{C}$.

Tissue Preparation

Medulla, hypothalamus and pons were homogenized in 10 $\mathrm{mmol} / \mathrm{l}$ Hepes buffer, $\mathrm{pH} 7.4$, containing $320 \mathrm{mmol} / \mathrm{l}$ sucrose, $1 \mathrm{mmol} / \mathrm{l} \mathrm{EDTA}, 1 \mathrm{mmol} / \mathrm{l} \mathrm{DTT}, 10 \mathrm{mg} / \mathrm{ml}$ leupeptin, $2 \mathrm{mg} / \mathrm{ml}$ aprotinin, and $1 \mu \mathrm{mol} / \mathrm{l}$ phenylmethylsulfunyl fluoride (PMSF) at $0-4^{\circ} \mathrm{C}$. A Polytron tissue mixing and blending device was used to blend the tissue into a smooth homogenate. Homogenates were centrifuged at $12,000 \mathrm{~g}$ for $5 \mathrm{~min}$ at $4^{\circ} \mathrm{C}$ to remove tissue debris and nuclear fragments. The supernatant was used to perform the Western blot analysis. Total protein concentration was deter- 


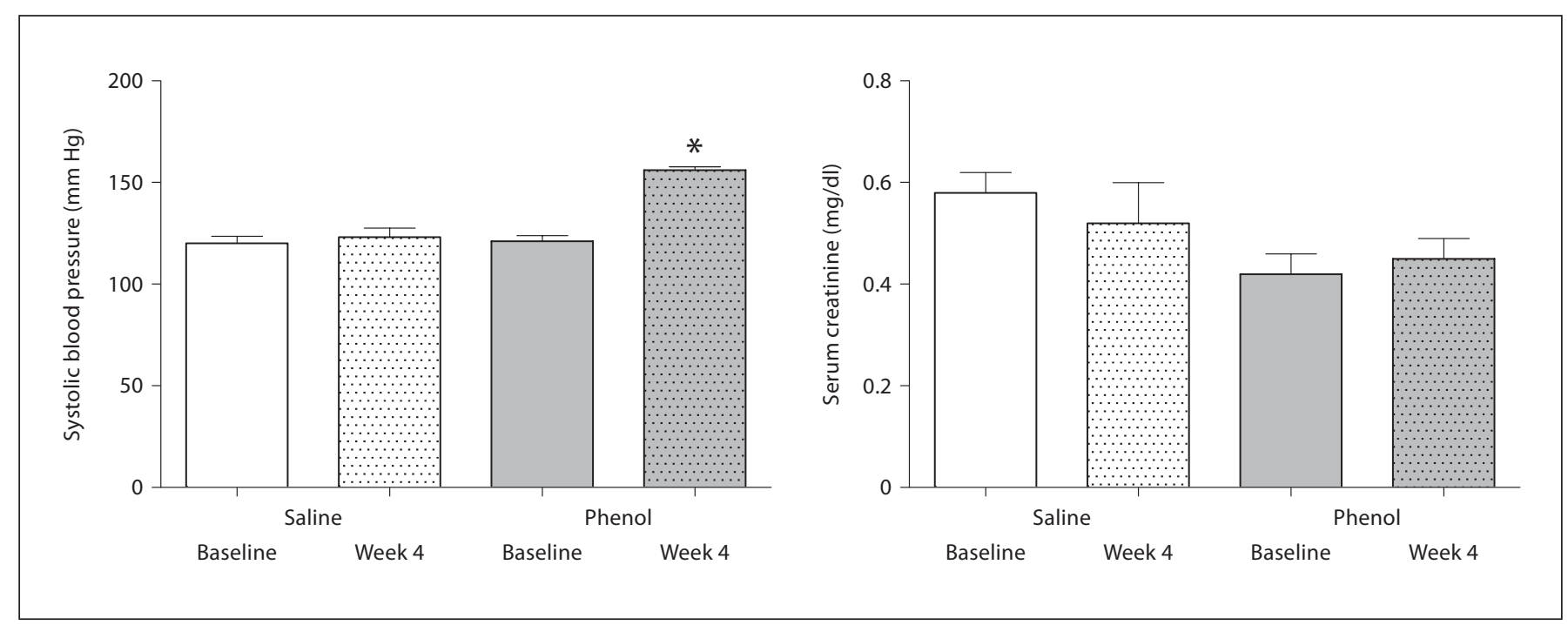

Fig. 1. Systolic arterial pressure and serum creatinine concentration in rats obtained at baseline and 4 weeks after injection of saline or phenol in the renal cortex. $n=6$ rats in each group; ${ }^{*} \mathrm{p}<0.05$.

mined with the use of a Bio-Rad kit (Bio-Rad Laboratories, Hercules, Calif., USA).

\section{Western Blot Analysis}

Protein abundance of NAD(P)H oxidase subunits (gp91 ${ }^{\text {phox }}$ $\mathrm{p} 47^{\text {phox }}, \mathrm{p} 67^{\text {phox }}$, and $\left.\mathrm{p} 22^{\text {phox }}\right)$, mitochondrial SOD (MnSOD) and cytoplasmic SOD (CuZnSOD) were measured by Western blot analysis as described in our earlier studies [22]. Polyclonal antibody against gp91 ${ }^{\text {phox }}$ was purchased from Upstate Inc. (Lake Placid, N.Y., USA). Antibody against $\mathrm{p} 47^{\text {phox }}$ was purchased from BD Biosciences Inc. (San Diego, Calif., USA), and polyclonal antibodies against P67 ${ }^{\text {phox }}$ were purchased from Upstate Inc. The anti-p22 $2^{\text {phox }}$ antibody was a generous gift from Dr. A.J. Jesaitis (Montana State University). Antibodies against CuZnSOD and MnSOD were purchased from Calbiochem Inc. (San Diego, Calif., USA). Western blot blue staining (PerkinElmer, Boston, Mass., USA) was used to verify the uniformity of protein load and transfer efficiency across the test samples. Experiments failing this test were discarded. Peroxidase-conjugated immunopure goat antirabbit IgG (H+L; Pierce Biotechnology Inc., Rockford, Ill., USA) and sheep anti-mouse IgG, HRP linked (Amersham ECL; GE Healthcare Inc., Piscataway, N.J., USA) were used as secondary antibodies and diluted in 5\% non-fat milk at 1:10,000. The monoclonal antibody against $\beta$-actin was purchased from Genetex Inc. (San Antonio, Tex., USA). Optical densities of the target protein bands were determined by a laser densitometer (Molecular Dynamics, Sunnyvale, Calif., USA), quantified with Image Quant 5.2 and normalized against those of $\beta$-actin.

Data Presentation and Analysis

Data are presented as mean \pm SEM. Student's t test and analysis of variance (ANOVA) were used in statistical evaluation of the data. $\mathrm{p}$ values $\leq 0.05$ were considered significant.

\section{Results}

\section{General Data}

Body weight and serum creatinine were unchanged (data not shown) while arterial pressure was significantly elevated in the phenol-injected rats as compared with the placebo-injected animals (fig. 1). Fractional excretion of sodium in the renal injury group was slightly lower than that found in the control animals $(0.68 \pm 0.1$ vs. $1.02 \pm$ $0.1, p \geq 0.05)$

\section{NAD $(P) H$ Oxidase Subunits}

Data are illustrated in figures $2-4$. The phenol-injected rats exhibited significant upregulation of gp91 ${ }^{\text {phox }}$, p $22^{\text {phox }}, \mathrm{p} 47^{\text {phox }}$ and $\mathrm{p} 67^{\text {phox }}$ in the medulla. In addition, gp91 ${ }^{\text {phox }}$ and $\mathrm{p} 22^{\text {phox }}$ were significantly increased in pons, and gp91 ${ }^{\text {phox }}$ abundance was elevated in the hypothalamus of the phenol-injected group as compared to the corresponding values found in the saline-injected controls.

\section{CuZnSOD and MnSOD}

Data are depicted in figures 5-7. MnSOD protein abundance was significantly increased in the medulla, hypothalamus and pons of the phenol-injected compared to the placebo-injected control group. CuZnSOD abundance was slightly increased in the hypothalamus and was unchanged in the medulla and pons of the phenolinjected group. 


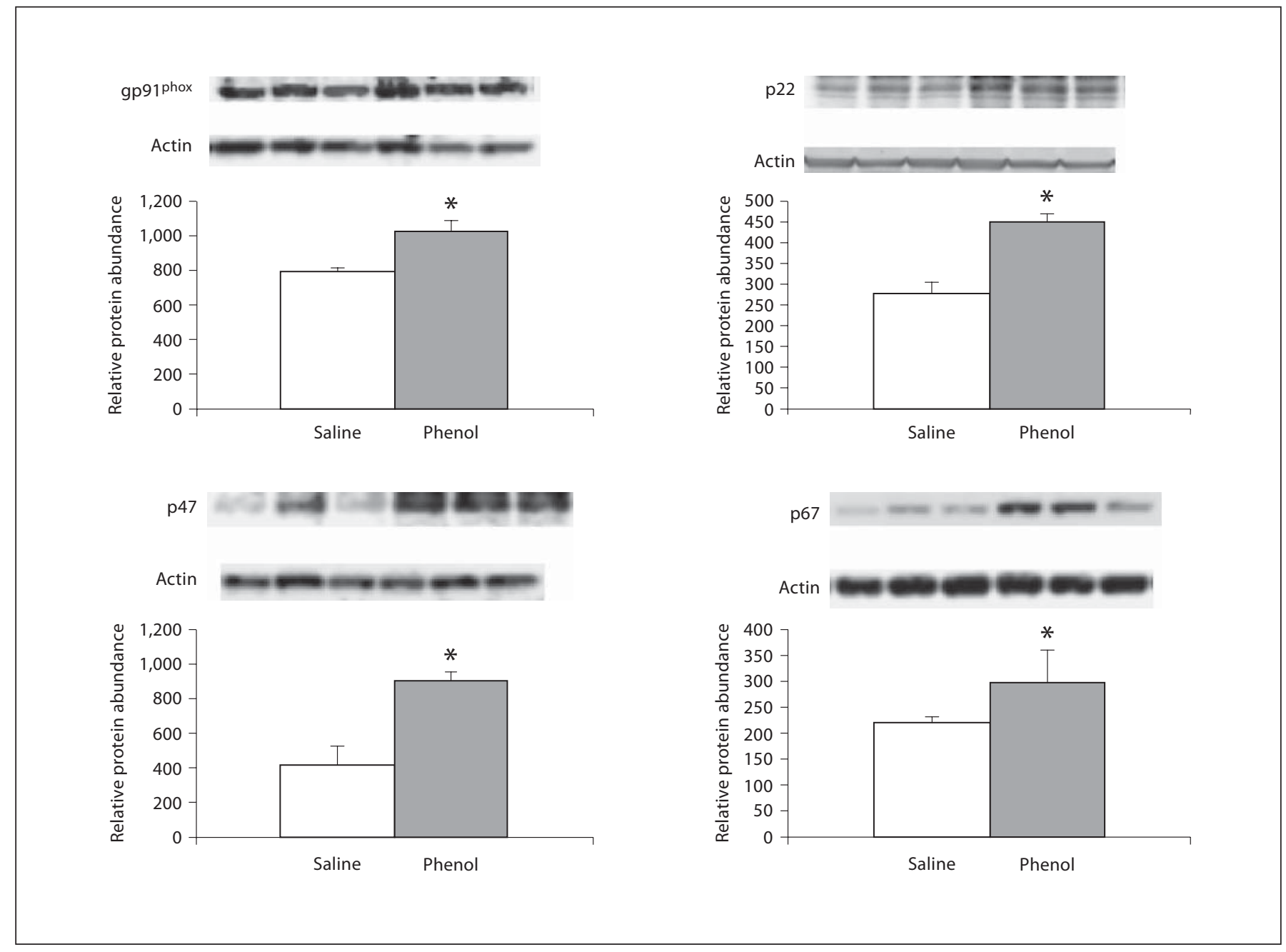

Fig. 2. Protein abundance of gp91 ${ }^{\text {phox }}, \mathrm{p} 22^{\text {phox }}, \mathrm{p} 47^{\mathrm{phox}}, \mathrm{p} 67^{\mathrm{phox}}$ in the medulla of rats obtained at baseline and 4 weeks after injection of saline or phenol in the renal cortex. $n=6$ rats in each group; ${ }^{*} \mathrm{p}<0.05$.

\section{Discussion}

Animals studied 4 weeks after injection of a small amount of phenol in the left kidney cortex exhibited a significantly higher arterial pressure than the placeboinjected animals, confirming the results of the previous studies in this model $[9,12,23]$. A previous study conducted in one of our laboratories showed that intrarenal injection of phenol in rats raises arterial pressure, augments norepinephrine secretion from posterior hypothalamic nuclei and increases renal sympathetic nerve activity $[12,23]$. A subsequent study demonstrated that intrarenal injection of phenol results in activation of sympathetic nervous system and an immediate increase in renal tubular sodium reabsorption [11]. The role of heightened renal sympathetic activity in this model was substantiated by subsequent experiments which demonstrated that HTN can be prevented by prior renal denervation $[12,23]$.

There is compelling evidence that ROS modulate activity of the neuronal pathways involved in regulation of blood pressure and cardiovascular function. Moreover, HTN in experimental animals is linked to increased levels of ROS in the cardiovascular centers of the brain stem (RVLM, NTS) and posterior hypothalamus. For instance, high levels of ROS have been shown in RVLM in spontaneously hypertensive rats $[24,25]$. In addition, injection of $\mathrm{H}_{2} \mathrm{O}_{2}$ into the 4 th ventricle has been shown to raise 


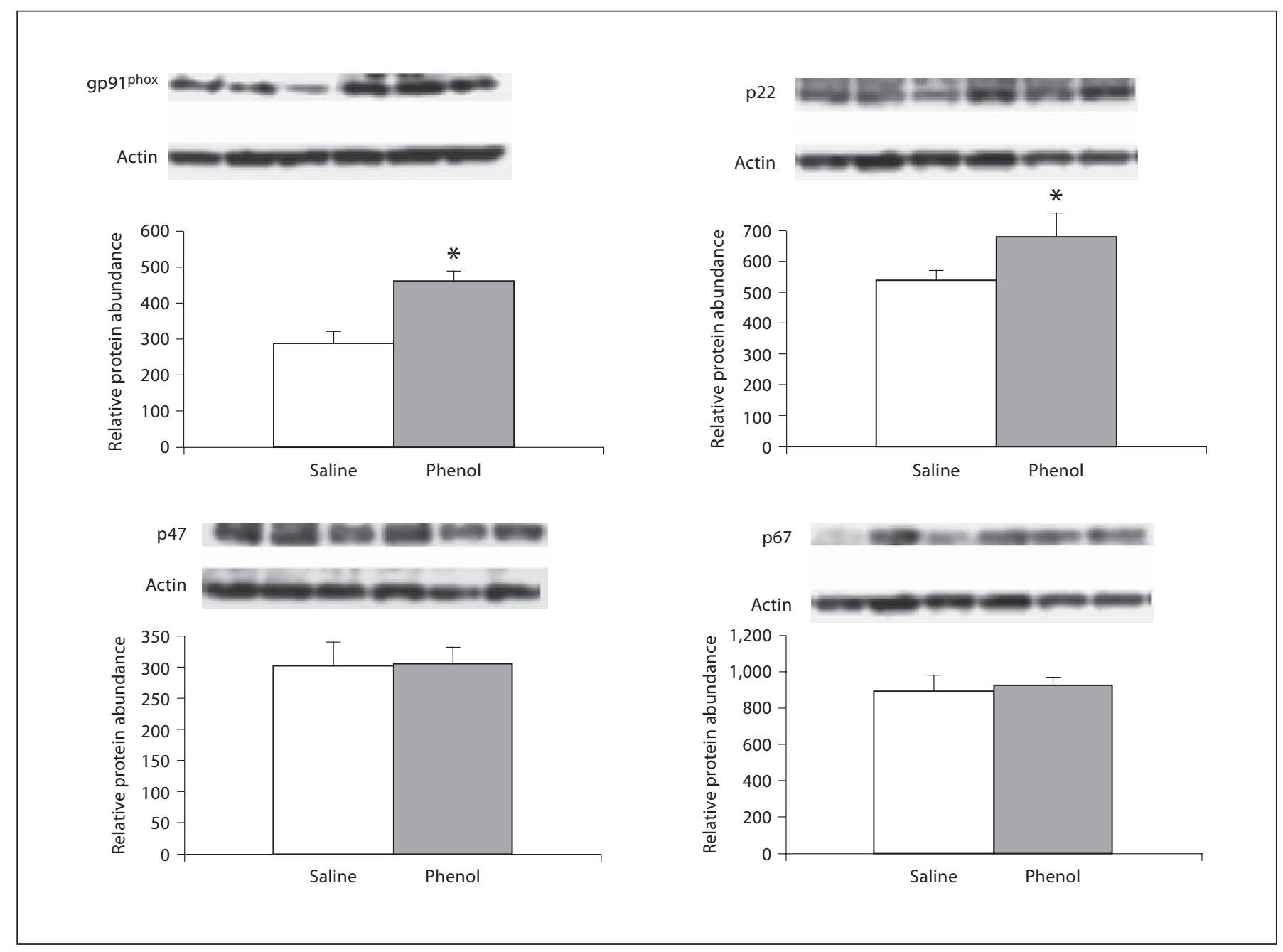

Fig. 3. Protein abundance of gp91 ${ }^{\text {phox }}, \mathrm{p} 22^{\text {phox }}, \mathrm{p} 47^{\text {phox }}, \mathrm{p} 67^{\text {phox }}$ in the pons of rats obtained at baseline and 4 weeks after injection of saline or phenol in the renal cortex. $\mathrm{n}=6$ rats in each group; ${ }^{*} \mathrm{p}<0.05$.

blood pressure and lower heart rate [20] in normotensive animals, events that were abrogated by $\alpha$-adrenergic receptor blockade with prazosin.

The prototypical phagocytic and tissue-specific isoforms of $\mathrm{NAD}(\mathrm{P}) \mathrm{H}$ oxidase are a major source of ROS production in the cellular constituents of various tissues including neuronal tissues [21, 26, 27]. The enzyme consists of two membrane-associated (gp91 ${ }^{\text {phox }}$ and $22^{\text {phox }}$ ) and three cytoplasmic (p47 ${ }^{\text {phox }}, \mathrm{p} 67^{\text {phox }}$, and $\mathrm{racl}$ ) subunits. Activation of the enzyme involves assembly of the cytoplasmic and membrane-associated subunits which is initiated by phosphorylation of the $\mathrm{p} 47^{\text {phox }}$ regulatory subunit. Once activated, NAD $(\mathrm{P}) \mathrm{H}$ oxidase, catalyzes single electron reduction of molecular oxygen to super- oxide, a highly reactive free radical species $\left(\mathrm{O}_{2}+\mathrm{e}-\rightarrow\right.$ $\mathrm{O}_{\overline{2}}^{\overline{2}}$ ). Several factors including pro-inflammatory cytokines, mechanical stress and angiotensin II promote p4 $7^{\text {phox }}$ phosphorylation leading to $\mathrm{NAD}(\mathrm{P}) \mathrm{H}$ oxidase activation and superoxide production in the target tissues. It is of note that gp91 ${ }^{\text {phox }}$, the catalytic subunit of $\mathrm{NAD}(\mathrm{P}) \mathrm{H}$ oxidase, is expressed on the neural processes of the NTS where it co-localizes with Ang II type 1 receptor [27]. In fact, ROS activity in the cardiovascular regions of brain stem is closely linked to the angiotensin II activity. For example, addition of Ang II to cultured neurons from the cardiovascular regions of the hypothalamus and brain stem increases neuronal firing, partly, through inhibition of K current, an effect which is associ- 


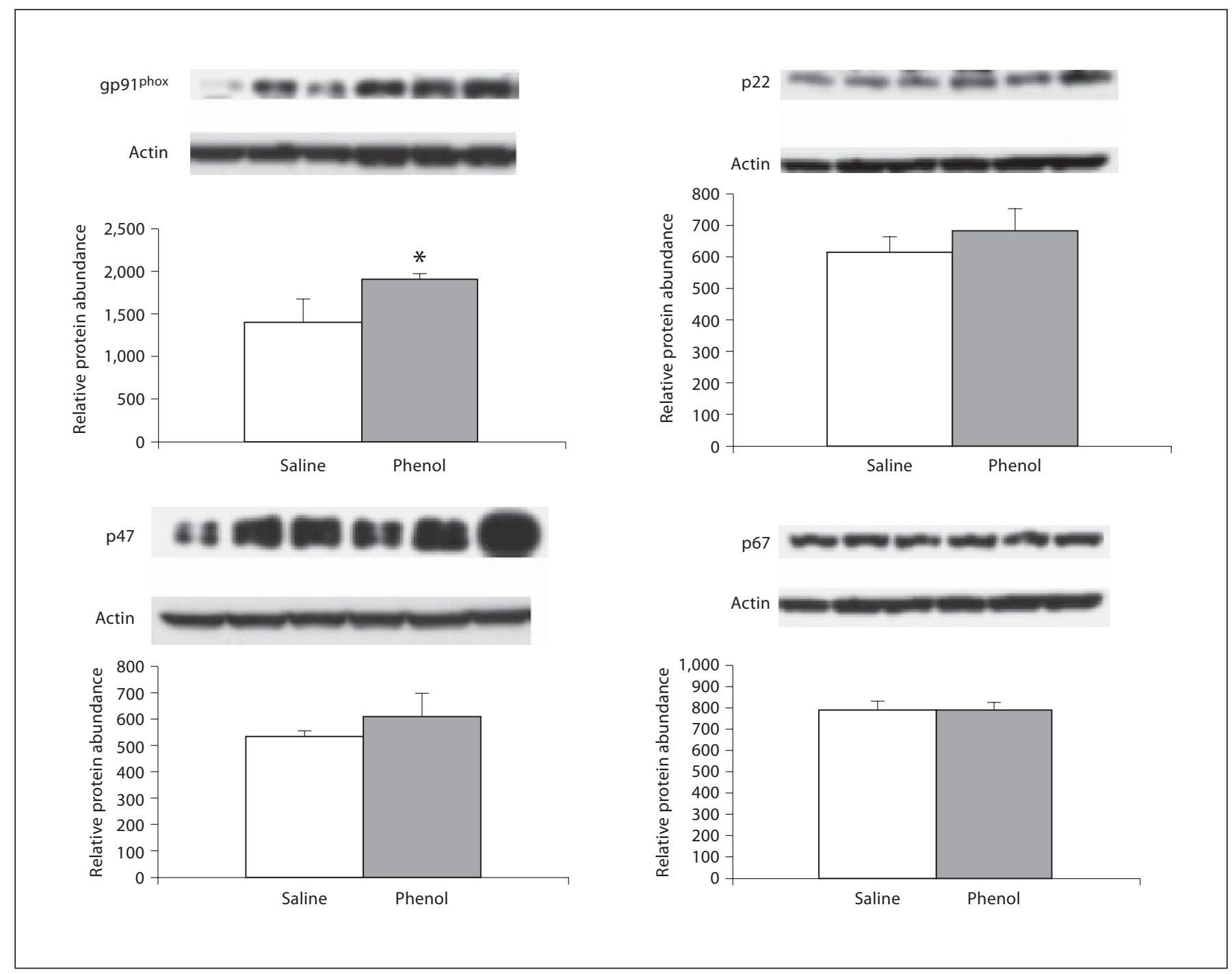

Fig. 4. Protein abundance of gp91 ${ }^{\text {phox }}, \mathrm{p} 22^{\mathrm{phox}}, \mathrm{p} 47^{\mathrm{phox}}, \mathrm{p} 67^{\mathrm{phox}}$ in the hypothalamus of rats obtained at baseline and 4 weeks after injection of saline or phenol in the renal cortex. $n=6$ rats in each group; ${ }^{*} \mathrm{p}<0.05$.

ated with increased $\mathrm{NAD}(\mathrm{P}) \mathrm{H}$ oxidase activity and ROS production in these neurons [28]. In rats, administration of SOD-mimetic drug, tempol, has been shown to completely abolish the effects of Ang II on blood pressure, norepinephrine secretion from the posterior hypothalamic nuclei and renal sympathetic nerve activity [29].

In rats, application of Ang II to RVLM causes $\mathrm{NAD}(\mathrm{P}) \mathrm{H}$ oxidase activation (phosphorylation of $\mathrm{p} 47^{\mathrm{phox}}$ ) and increased superoxide production, events which are prevented by pretreatment with $\mathrm{NAD}(\mathrm{P}) \mathrm{H}$ oxidase inhibitors [30]. Likewise, pretreatment of RVLM nucleus with gp91ds-tat, a specific gp91 inhibitor, suppresses the phys- iological action of Ang II [28] and mice lacking p47phox fail to show hypertensive response to Ang II infusion [31]. Finally, in rabbits, angiotensin upregulates expression of p40 ${ }^{\text {phox }}, \mathrm{p} 47^{\text {phox }}$, p6 6 phox $^{\text {pp }}$ 91 ${ }^{\text {phox }}$ and increases NAD (P)H oxidase-dependent production of superoxide [32].

Rats with chronic neurogenic HTN studied 5 weeks after intrarenal phenol injection, exhibited significant upregulation of $\mathrm{gp} 91^{\text {phox }}$, the catalytic subunit of $\mathrm{NAD}(\mathrm{P}) \mathrm{H}$ oxidase in the medulla, hypothalamus and pons. Similarly, the enzyme's second membrane-associated subunit, $\mathrm{p} 22^{\text {phox }}$, and its important regulatory subunit, $\mathrm{p} 47^{\text {phox }}$, were upregulated in most of the tested re- 


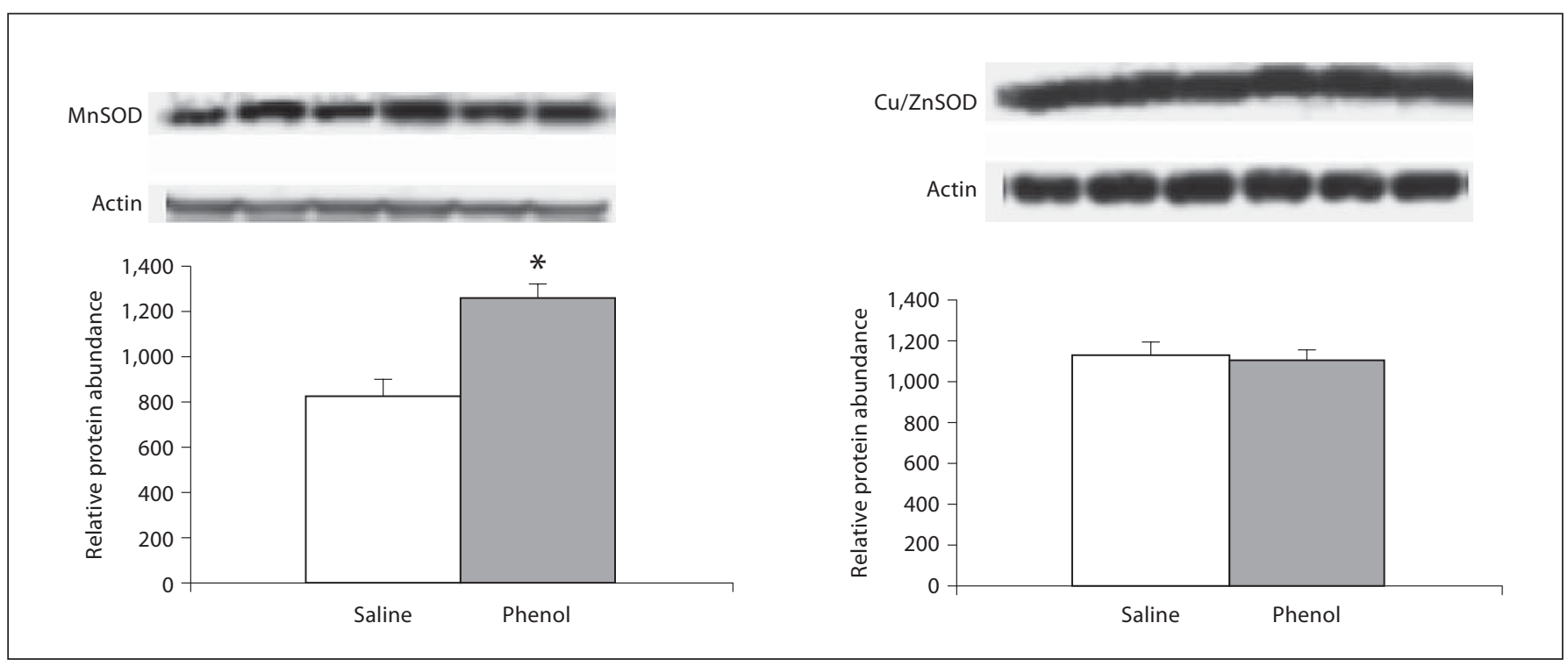

Fig. 5. Protein abundance of MnSOD and CuZnSOD in the medulla of rats obtained at baseline and 4 weeks after injection of saline or phenol in the renal cortex. $n=6$ rats in each group; ${ }^{*} p<0.05$.

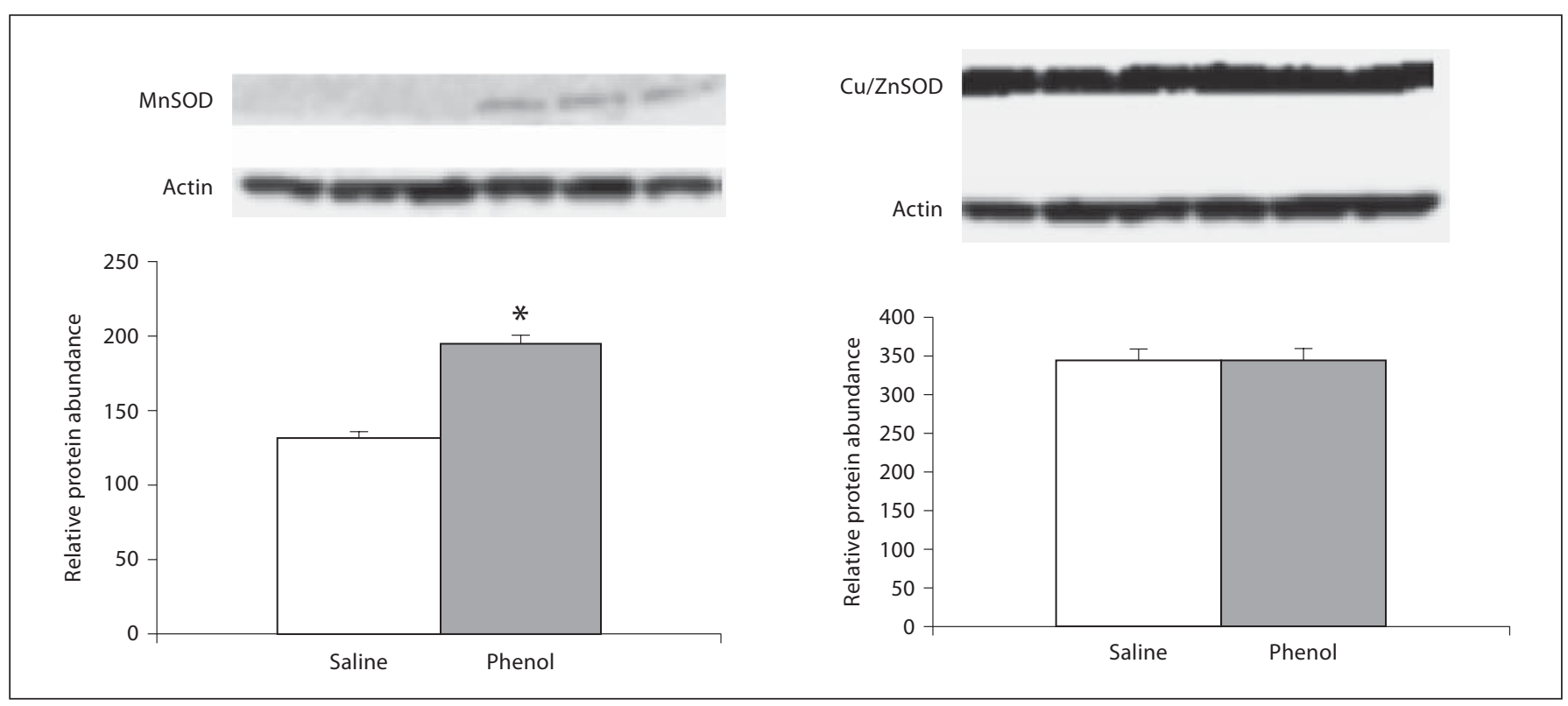

Fig. 6. Protein abundance of MnSOD and CuZnSOD in the pons of rats obtained at baseline and 4 weeks after injection of saline or phenol in the renal cortex. $\mathrm{n}=6$ rats in each group; ${ }^{*} \mathrm{p}<0.05$.

gions of the brain in our rats with renal-injury-induced neurogenic HTN. Together, these observations point to increased superoxide-generating capacity of the key regions of the brain involved in regulation of blood pressure and cardiovascular function in this model. In addi- tion, the study extends the findings of an earlier investigation which showed a rapid rise in mRNA abundance of $\mathrm{NAD}(\mathrm{P}) \mathrm{H}$ oxidase subunits in this model shortly after intrarenal injection of phenol [10]. 


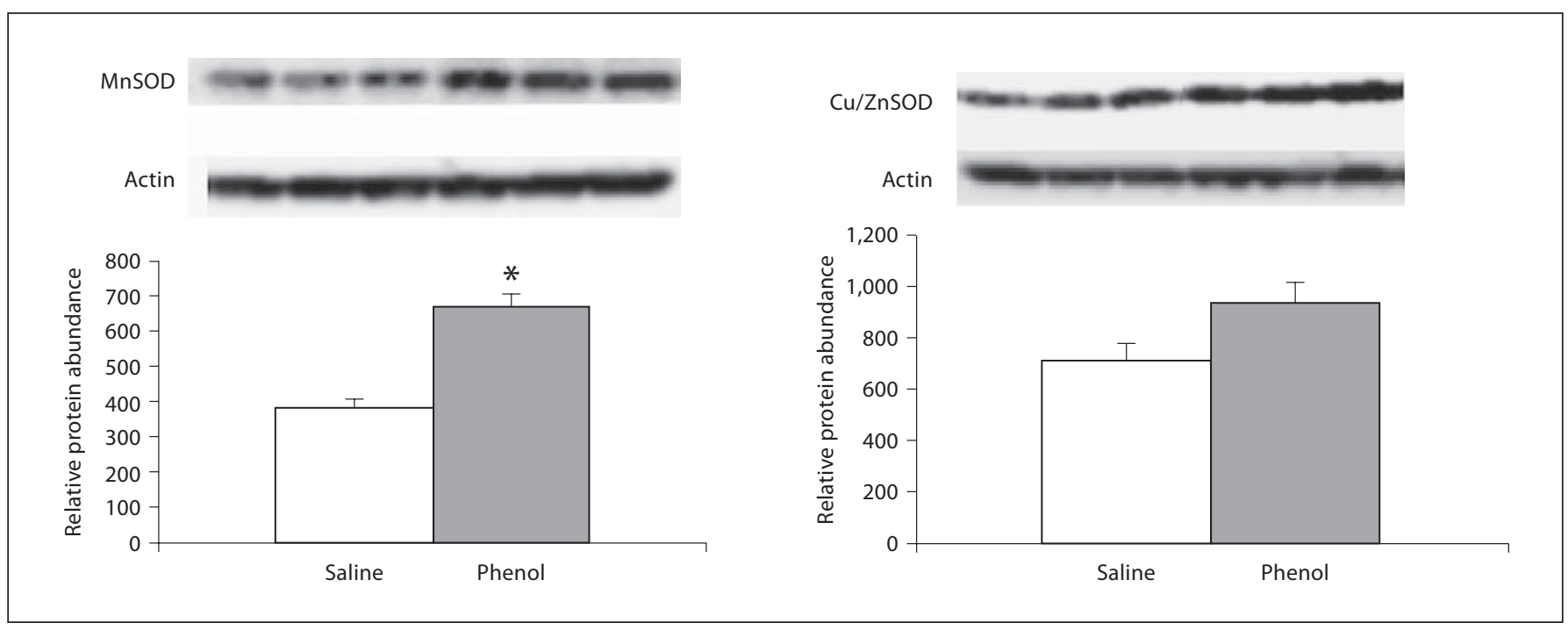

Fig. 7. Protein abundance of MnSOD and CuZnSOD in the hypothalamus of rats obtained at baseline and 4 weeks after injection of saline or phenol in the renal cortex. $n=6$ rats in each group; ${ }^{*} \mathrm{p}<0.05$.

Superoxide is converted to hydrogen peroxide by a family of enzymes known as superoxide dismutase (SOD) comprising cytoplasmic (CuZnSOD), mitochondrial (MnSOD) and extracellular (EC-SOD) isoforms. Expression of SOD is upregulated by superoxide and SOD deficiency results in elevation of superoxide level. The SOD content of RVLM is reduced in stroke-prone spontaneously hypertensive rats [24] and administration of SODmimetic drug, tempol, attenuates HTN in spontaneously hypertensive rats [24, 25]. Microinjection of SOD into the RVLN reduces arterial pressure and renal sympathetic activity in both normo- and hypertensive pigs [33]. In stress-induced HTN model, bilateral microinjection of tempol into the RVLM or posterior hypothalamus attenuates sympathoexcitatory and pressor response to air jet in rabbits [34, 35]. Similarly, intraventricular infusion of SOD or tempol prevents the acute rise in blood pressure in response to intrarenal injection of phenol [10].

ROS can influence the activities of central neuronal pathways involved in regulation of arterial pressure and cardiovascular system by several mechanisms. For instance, ROS influence neuronal firing in RVLM and posterior hypothalamus by modulating the activity of calcium or potassium channels. Ang II activates calcium currents [36] by promoting superoxide production via the $\mathrm{rac1} / \mathrm{NAD}(\mathrm{P}) \mathrm{H}$ oxidase system [37]. This assertion is supported by the fact that gp91ds-tat which disables the gp91 catalytic subunit of NAD $(\mathrm{P}) \mathrm{H}$ oxidase, blocks the Ang II- mediated enhancement of L-type calcium currents [27]. Similarly, angiotensin-induced superoxide production by $\mathrm{NAD}(\mathrm{P}) \mathrm{H}$ oxidase, increases calcium currents in NTS neurons [27].

Using the inside-outside patch clamping technique, Sun et al. [28] have shown that increased production of superoxide in the brain stem neurons regardless of its source can directly close potassium channels which, in turn, influence membrane conductance and increase neuronal firing. Alternatively, superoxide can influence neuronal firing by inhibiting protein phosphatases that inactivate calcium/calmodulin kinase II, thereby sustaining potassium current [38]. In addition, high levels of ROS can have a long-lasting impact on the structure/ function of these regions of the brain through transcriptional mechanisms. For instance, high levels of ROS in brain stem nuclei (RVLM, NTS) may affect blood pressure regulation though activation of redox-sensitive nuclear factors leading to transcription of such genes as SOD, Ca-calmodulin kinase-II, and NO synthase, among others [39]. Moreover, via inactivation of nitric oxide and inhibition of NO synthase, ROS can heighten central sympathetic activity which is normally suppressed by NO [40].

Upregulation of the superoxide-generating enzyme, $\mathrm{NAD}(\mathrm{P}) \mathrm{H}$ oxidase in the brain regions involved in central regulation of noradrenergic activity in phenol-injected rats employed in the present study was accompanied 
by increased MnSOD in the pons and medulla but not hypothalamus. In addition, CuZnSOD was unchanged in all tested regions of the brain. These findings represent a partial compensatory response to heightened ROS production in the given regions of the brain in phenol-injected animals.

In conclusion, chronic neurogenic HTN induced by intrarenal injection of phenol is associated with upregulation of the superoxide-generating enzyme, $\mathrm{NAD}(\mathrm{P}) \mathrm{H}$ oxidase in the medulla, pons and hypothalamus. These findings point to increased ROS production capacity in the key regions of the brain involved in regulation of blood pressure and cardiovascular function. Given the role of ROS in stimulating central noradrenergic activity, the observed maladaptive changes may, in part, contribute to the genesis and maintenance of HTN in this model.

\section{Acknowledgement}

This study was funded by National Heart, Lung and Blood Institute grant RO1-HL071792-04.

\section{References}

$\checkmark$ Recordati G, Moss NG, Genovesi S, Rogenes P: Renal chemoreceptors. J Auton Nerv Syst 1981;3:237-251.

-2 Stella A, Golin R, Genovesi S, Zanchetti A: Renal reflexes in the regulation of blood pressure and sodium excretion. Can J Physiol Pharmacol 1987;65:1536-1539.

-3 Katholi RE: Renal nerves and hypertension: an update. Fed Proc 1985;44:2846-2850.

4 DiBona GF: The function of the renal nerves. Rev Physiol Biochem Pharmacol 1982;94: 75-181.

5 Kopp UC, Olson LA, DiBona GF: Renorenal reflex responses to mechano- and chemoreceptors stimulation in the dog and rat. Am J Physiol 1984;241:R286-R292.

6 Faber JE, Brody MJ: Afferent renal nerve-dependent hypertension following acute renal artery stenosis in the conscious rat. Circ Res 1985;57:676-688.

7 Calaresu FR, Ciriello J: Renal afferent nerves affect discharge rate of medullary and hypothalamic single units in cat. J Auton Nerv Syst 1981;3:311-320.

-8 Ciriello J, Calaresu FR: Central projection of afferent renal fibers in the rat: an anterograde transport study of horseradish peroxidase. J Auton Nerv Syst 1983;8:273-285

$\checkmark 9$ Campese VM: Neurogenic factors and hypertension in renal disease. Kidney Int Suppl 2000;75:S2-S6.

10 Ye S, Zhong H, Campese VM: Oxidative stress mediates the stimulation of sympathetic nerve activity in the phenol renal injury model of hypertension. Hypertension 2006;48:309-315.

11 Yang LE, Zhong H, Leog PK, Perianayagam A, Campese VM, McDonough AA: Chronic renal injury-induced hypertension alters renal NHE3 distribution and abundance. Am J Physiol Renal Physiol 2003;284:F1056F1065.
12 Ye S, Gamburd M, Mozayeni P, Koss M, Campese VM: A limited renal injury may cause a permanent form of neurogenic hypertension. Am J Hypertens 1998;11:723728.

13 Dampney RA: Functional organization of central pathways regulating the cardiovascular system. Physiol Rev 1994;74:323-364.

14 Takeda K, Bunag RD: Sympathetic hyperactivity during hypothalamic stimulation in spontaneously hypertensive rats. J Clin Invest 1978;62:642-648.

15 Vaziri ND, Rodriguez-Itrube B: Mechanisms of disease: oxidative stress and inflammation in the pathogenesis of hypertension. Nat Clin Pract Nephrol 2006;2:582-593.

$16 \mathrm{Xu} \mathrm{H}$, Fink GD, Galligan JJ: Tempol lowers blood pressure and sympathetic nerve activity but not vascular $\mathrm{O}_{2}^{-}$in DOCA-salt rats. Hypertension 2004;43:329-338.

17 Campese VM, Ye S, Zhong H, Yanamadala V, Ye Z, Chiu J: Reactive oxygen species stimulate central and peripheral sympathetic nervous system activity. Am J Physiol 2004;287: H695-H703.

18 Han Y, Zhang Y, Wang HJ, Gao XY, Wang W, Zhu GQ: Reactive oxygen species in paraventricular nucleus modulates cardiac sympathetic afferent reflex in rats. Brain Res 2005; 1058:82-90.

19 Danson E, Paterson D: Reactive oxygen species and autonomic regulation of cardiac excitability. J Cardiovasc Electrophysiol 2006; 17:S104-S112.

20 Máximo Cardoso L, de Almeida Colombari DS, Vanderlei Menani J, Alves Chianca D Jr, Colombari E: Cardiovascular responses produced by central injection of hydrogen peroxide in conscious rats. Brain Res Bull 2006; 71:37-44.

21 Griendling KK: Novel NAD(P)H oxidases in the cardiovascular system. Heart 2004;90: 491-493.
22 Vaziri ND, Lee YS, Lin CY, Lin VW, Sindhu RK: NAD(P)H oxidase, superoxide dismutase, glutathione peroxidase and nitric oxide synthase expression in subacute spinal cord injury. Brain Res 2004;995:76-83.

23 Ye S, Ozgur B, Campese VM: Renal afferent impulses, the posterior hypothalamus, and hypertension in rats with chronic renal failure. Kidney Int 1997;51:722-727.

24 Kishi T, Hirooka Y, Kimura Y, Ito K, Shimokawa $\mathrm{H}$, Takeshita A: Increased reactive oxygen species in rostral ventrolateral medulla contribute to neural mechanisms of hypertension in stroke-prone spontaneously hypertensive rats. Circulation 2004; 109:23572362.

25 Tai MH, Wang LL, Wu KL, Chan JY: Increased superoxide anion in rostral ventrolateral medulla contributes to hypertension in spontaneously hypertensive rats via interactions with nitric oxide. Free Radic Biol Med 2005;38:450-462.

26 Chabrashvili T, Tojo A, Onozato ML, Kitiyakara C, Quinn MT, Fujita T, Welch WJ, Wilcox CS: Expression and cellular localization of classic NADPH oxidase subunits in the spontaneously hypertensive rat kidney. Hypertension 2002;39:269-274.

27 Wang G, Anrather J, Huang J, Speth RC, Pickel VM, Iadecola C: NADPH oxidase contributes to angiotensin II signaling in the nucleus tractus solitarius. J Neurosci 2004;24: 5516-5524.

28 Sun C, Sellers KW, Sumners C, Raizada MK: $\mathrm{NAD}(\mathrm{P}) \mathrm{H}$ oxidase inhibition attenuates neuronal chronotropic actions of angiotensin II. Circ Res 2005;96:659-666.

29 Campese VM, Ye SH, Zhong H: Oxidative stress mediates angiotensin II-dependent stimulation of sympathetic nerve activity. Hypertension 2005;46:533-539. 
-30 Chan JY, Chan SH, Li FC, Tsai CY, Cheng HL, Chang AY: Phasic cardiovascular responses to mevinphos are mediated through differential activation of cGMP/PKG cascade and peroxynitrite via nitric oxide generated in the rat rostral ventrolateral medulla by NOS I and II isoforms. Neuropharmacology 2005;48:161-172.

- 31 Landmesser U, Spiekermann S, Dikalov S, Tatge H, Wilke R, Kohler C, Harrison DG, Hornig B, Drexler H: Vascular oxidative stress and endothelial dysfunction in patients with chronic heart failure: role of xanthine-oxidase and extracellular superoxide dismutase. Circulation 2002;106: 3073-3078.

-32 Gao L, Wang W, Li YL, Schultz HD, Liu D, Cornish KG, Zucker IH: Simvastatin therapy normalizes sympathetic neural control in experimental heart failure: roles of angiotensin II type 1 receptors and $\mathrm{NAD}(\mathrm{P}) \mathrm{H}$ oxidase. Circulation 2005;112:1763-1770.
33 Zanzinger J, Czachurski J: Chronic oxidative stress in the RVLM modulates sympathetic control of circulation in pigs. Pflügers Arch 2000;439:489-494.

34 De Matteo R, Head GA, Mayorov DN: Tempol in the dorsomedial hypothalamus attenuates the hypertensive response to stress in rabbits. Am J Hypertens 2006;19:396-402.

35 Mayorov DN, Head GA, De Matteo R: Tempol attenuates excitatory actions of angiotensin II in the rostral ventrolateral medulla during emotional stress. Hypertension 2004; 44:101-106.
36 Sumners C, Fleegal MA, Zhu M: Angiotensin AT1 receptor signalling pathways in neurons. Clin Exp Pharmacol Physiol 2002;29: 483-490.

37 Zimmerman MC, Sharma RV, Davisson RL: Superoxide mediates angiotensin II-induced influx of extracellular calcium in neural cells. Hypertension 2005;45:717-723.

38 Hongpaisan J, Winters CA, Andrews SB: Strong calcium entry activates mitochondrial superoxide generation, upregulating kinase signaling in hippocampal neurons. J Neurosci 2004;24:10878-10887.

$>39$ Meffert MK, Baltimore D: Physiological functions for brain NF- $\kappa$ B. Trends Neurosci 2005;28:37-43.

$\checkmark 40$ Ye S, Nosrati S, Campese VM: Nitric oxide modulates the neurogenic control of blood pressure in rats with chronic renal failure. J Clin Invest 1997;99:540-548. 